\title{
Pemberdayaan Keluarga Pasien Stroke Afasia Melalui Pelatihan Komunikasi Verbal
}

\author{
Amila ${ }^{1}$ \\ Universitas Sari Mutiara Indonesia,mila_difa@yahoo.co.id \\ Evarina Sembiring ${ }^{2}$ \\ Universitas Sari Mutiara Indonesia, evarina765@yahoo.com \\ Janno Sinaga ${ }^{3}$ \\ Universitas Sari Mutiara Indonesia, jnsm@gmail.com
}

\begin{abstract}
Abstrak
Terbatasnya terapi wicara di rumah sakit, penanganan stroke lebih kearah penyebab stroke/medis, sedang gejala sisa belum mendapat penanganan sampai pasien pulang. Gangguan tersebut menyebabkan pasien tidak mampu mengungkapkan apa yang diinginkan pasien, tidak mampu menjawab pertanyaan atau berpartisipasi dalam percakapan. Selanjutnya pasien akan menarik diri dari kegiatan sosial, rendah diri, depresi dan kondisi pasien akan semakin buruk. Penanganan terpadu dengan anggota keluarga merupakan faktor yang cukup penting dan kunci keberhasilan dalam proses penanganan gangguan komunikasi verbal. Untuk mencegah terjadinya depresi pada pasien dan keluarga maka diperlukan media komunikasi pengganti komunikasi verbal, seperti buku komunikasi. Tujuan pelatihan adalah mengatasi permasalahan gangguan komunikasi verbal pasien stroke setelah pulang ke rumah. Metode yang digunakan dalam pelatihan ini adalah latihan komunikasi seperti menyebutkan gambar, menunjuk, menulis dan membaca melalui booklet komunikasi. Hasil yang dicapai dalam pelatihan adalah meningkatkan kemampuan bahasa dan berkomunikasi, interaksi antara pasien dengan keluarga, meningkatkan kemandirian dan perkembangan hubungan sosial dengan orang lain. Disarankan untuk dikembangkan kemitraan yang luas berupa pelatihan komunikasi verbal dan sosialisasi booklet komunikasi untuk meningkatkan interaksi sosial dan mengurangi depresi pasien dan keluarga.
\end{abstract}

Kata Kunci : Gangguan komunikasi verbal, Pemberdayaan keluarga, Stroke afasia

\begin{abstract}
There is limited speech therapy in the hospital, handling more strokes towards the cause of stroke, while the sequelae have not received treatment until the patiens return home. The disorder cause the patient to be unable to express what the patient wants, is unable to answer questions or participate in conversations. Futhermore, patiens will withdraw from social activities, low self esteem, depression and the patients's condition will get worse. Integrated handling with family members is a fairly important factor and the key to success in the process of handling verbal communication disorders. The purpose of this exercises is to overcome the problem of verbal communication disorder of stroke patients after returning home. The method used in this exercises is communication exercises such as mentioning images, pointing,
\end{abstract}




\section{JURNAL ABDIMAS BSI}

Jurnal Pengabdian Kepada Masyarakat

writing and reading by communication books, familie. The results achieved in this exercises were improving languageskills and communication, increasing interaction between patients and families, the independence and development of social relationships with others. It is recommended to develop a broad partnership in the form of verbal communication training and socialization of communication booklets to improve social interaction and reduce depression in patients and families.

Keywords : Verbal communication disorder, Family empowerment, Aphasia stroke

\section{Pendahuluan}

Stroke yaitu suatu kondisi yang terjadi ketika pasokan darah ke suatu bagian otak tiba-tiba terganggu, karena sebagian sel-sel otak mengalami kematian akibat gangguan aliran darah karena sumbatan atau pecahnya pembuluh darah otak (Nabyl, 2012).

Berdasarkan data Riset Kesehatan Dasar 2013, prevalensi stroke tertinggi terdapat di Sulawesi Selatan $(17,9)$. Sementara itu di Sumatera Utara prevalensi penyakit stroke sebesar 6,3\% (Ministry of Health Indonesia, 2019). Menurut data Puskesmas Helvetia Medan 2016, sekitar 25\% pasien atau 1400 pasien hipertensi mengalami stroke yang tersebar di tujuh kelurahan Medan Helvetia yang memerlukan perawatan di Rumah Sakit. Jumlah pasien stroke di Mutiara Home Care Medan bulan Januari-Desember 2018 sekitar 312 orang.

Setiap tahun hampir 700.000 orang Amerika mengalami stroke dan stroke mengakibatkan hampir 150.000 kematian. Stroke telah menjadi penyebab kematian utama hampir di semua rumah sakit di Indonesia $(14,5 \%)$.

Pada umumnya setelah pulang dari rumah sakit, pasien stroke membawa gejala sisa, misalnya bicara cadel (pelo), ketergantungan kebutuhan sehari-hari, gangguan dalam berkomunikasi verbal dan sebagainya. Gangguan komunikasi verbal yang ditemukan berupa kesulitan mengungkapkan sesuatu yang diinginkan, kesulitan membentuk kata dan kesulitan memahami pembicaraan orang lain. Keluarga sering mengabaikan karena tidak memahami apa yang disampaikan, dan apa keinginan pasien. Pasien merasa tidak punya harapan hidup lagi karena sejumlah keterbatasan yang dimiliki. Selanjutnya pasien akan menarik diri dari kegiatan sosial, rendah diri dan kondisi pasien akan semakin buruk. Keluarga yang merawat penderita stroke juga akan mengalami stress karena tidak mengerti apa yang diinginkan oleh penderita, kondisi ini perlu penanganan therapis berupa pelatihan komunikasi verbal, sehingga dampak gejala sisa dari serangan stroke tidak bertambah berat.

Selain itu, di rumah sakit terbatas sumber daya dibidang terapi wicara, sehingga pasien tidak dilakukan deteksi dan rehabilitasi terhadap komunikasi verbal sejak pasien masuk rumah sakit sampai pasien pulang. Padahal tahap yang harus dilakukan setelah pasien selesai menjalani terapi di rumah sakit sakit adalah terapi wicara. Sehingga bila pasien sudah diperbolehkan pulang, keluarga tidak perlu menyewa 
petugas rehabilitasi medis, tetapi keluarga bisa melakukannya sendiri. Disamping lebih hemat biaya, pasien merasa mendapat dukungan hidup karena dibantu oleh salah satu anggota keluarga. Perlunya peran keluarga karena proses penyembuhan stroke membutuhkan waktu yang relatif lebih lama. Karena itu rehabilitasi menjadi sangat penting dalam proses penyembuhan pasien, meningkatkan kemampuan pasien dan mencegah memburuknya gejala sisa stroke.

Diperkirakan sekitar 53\% pasien dengan gangguan komunikasi mengalami depresi (Thomas \& Lincoln, 2008). Depresi pada stroke ini menghambat pemulihan fungsi kognitif, mengganggu aktivitas hidup sehari - hari dan meningkatkan kematian. Depresi juga berdampak pada orang yang merawat pasien dan menghambat komunikasi diantara keluarga dan pasien. Untuk mencegah depresi pada pasien stroke diperlukan keterlibatan keluarga dan membantu dalam latihan berkomunikasi. Penanganan terpadu dengan anggota keluarga pasien stroke merupakan faktor yang cukup penting dan kunci keberhasilan dalam proses penanganan gangguan komunikasi verbal. Menurut Salter, Foley \& Teasell (2006), peningkatan dukungan keluarga yang tersedia dapat menjadi strategi penting dalam mengurangi atau mencegah tekanan jiwa dan depresi paska stroke. Untuk mencegah masalah-masalah tersebut diperlukan booklet komunikasi visual.

Booklet komunikasi sebagai pengganti komunikasi verbal yang berisi tulisan atau gambar kebutuhan sehari-hari yang dapat ditunjuk oleh pasien. Efektifitas latihan komunikasi akan meningkat jika latihan menggunakan bentuk stimulus audio dalam bentuk musik dan stimulus visual dalam bentuk gambar - gambar serta lukisan (Kusumoputro, 1992).

Booklet komunikasi visual dapat membantu pasien untuk berkomunikasi dengan perawat/ keluarga untuk mengekspresikan kebutuhannya. Buku komunikasi ini berisi kegiatan pasien sehari - hari yang selalu dilakukan, seperti setiap pasien mau makan, minum, mandi, menggosok gigi, menyisir rambut, berpakaian, BAB, BAK, penggunaan toilet, istirahat dan tidur, miring kanan/kiri, duduk bersandar, minum obat, mobilisasi dan lain - lain. Pasien mampu menunjukkan gambar yang ada dibuku komunikasi untuk mengkomunikasikan kebutuhannya. Pasien juga dapat mengulang nama gambar tersebut, menyebutkan gambar, membaca, mengeja dan menulis sebagai latihan komunikasi.

Booklet komunikasi ini banyak memberikan keuntungan, seperti meningkatkan kemampuan bahasa dan berkomunikasi, meningkatkan interaksi antara pasien dengan keluarga, meningkatkan kemandirian dan perkembangan hubungan sosial dengan orang lain. Hal ini dapat mengurangi jumlah biaya yang harus dikeluarkan akibat depresi. Hasil yang dicapai pada pemberian alat bantu komunikasi adalah kualitas hidup. Keadaan ini dapat terjadi karena pasien yang menggunakan alat bantu komunikasi pada umumnya memiliki kepuasan dalam hubungan dengan keluarga, teman dan aktivitas hidup yang menyenangkan (Wikipedia, 2018). 
Tujuan kegiatan pelatihan adalah mengatasi permasalahan gangguan komunikasi verbal pasien stroke setelah pulang ke rumah.

Manfaat kegiatan adalah agar pasien dapat mengkomunikasi kebutuhannya sehingga tidak terjadi gangguan interaksi sosial, depresi dan gangguan psikososial lainnya melalui alat bantu komunikasi seperti booklet komunikasi visual .

\section{Metode Pelaksanaan}

Solusi yang dilakukan untuk menyelesaikan permasalahan mitra adalah melakukan pelatihan komunikasi verbal. Pelaksanaan kegiatan ini dilakukan dengan melibatkan pasien stroke dan keluarga yang berada di Mutiara Home Care Kelurahan Dwikora Medan dengan gangguan komunikasi paska stroke. Pelaksanaan kegiatan meliputi :

a. Membuat booklet komunikasi visual untuk memfasilitasi komunikasi pasien stroke dengan gangguan komunikasi verbal antara pasien dan keluarga.

b. Melibatkan keluarga dan pasien untuk melatih/ memfasilitasi komunikasi dengan gangguan komunikasi verbal.

c. Memberikan pelatihan cara menggunakan booklet komunikasi visual untuk memfasilitasi masalah komunikasi pasien paska stroke seperti teknik berkomunikasi, menjelaskan gambar/simbol dalam booklet dan memberikan latihan/rehabilitasi komunikasi (menunjuk gambar, menyebutkan, mengulang, menulis dan membaca tulisan gambar).

\section{Hasil dan Pembahasan}

Hasil pengumpulan data kepuasan keluarga terhadap pendampingan keluarga yang diberikan perawat setelah kegiatan pelatihan tersaji sebagai berikut:

Tabel 1. Distribusi Keluarga berdasarkan Kepuasan Pelatihan Komunikasi Verbal

\begin{tabular}{llll}
\hline No & Kategori & Persentase & Frekuensi \\
\hline 1 & Puas & 25 & 71.43 \\
2 & Tidak Puas & 10 & 28.57 \\
\hline
\end{tabular}
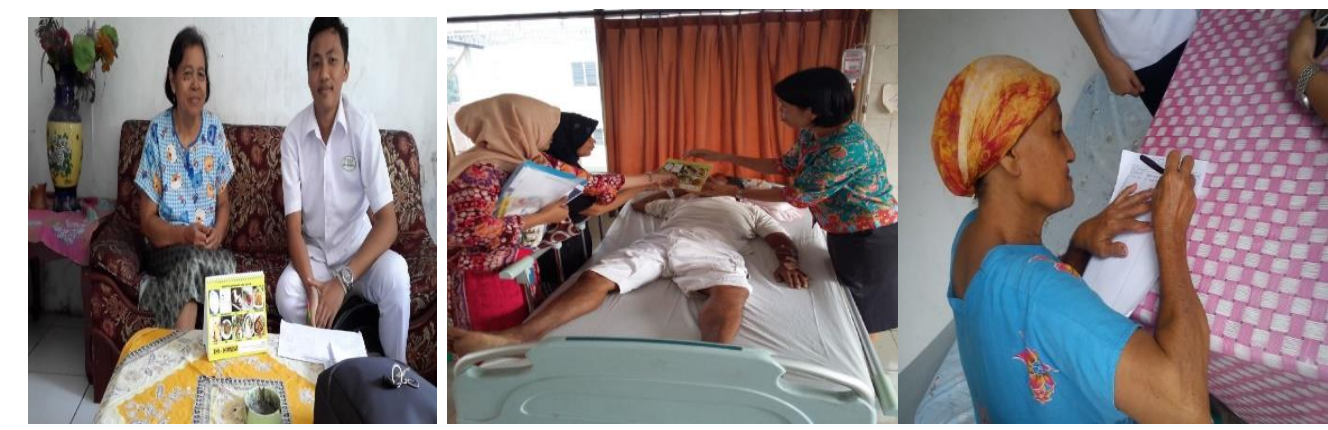

Gambar 1. Pelatihan Komunikasi Verbal

Hasil yang diperoleh dari pengumpulan data ini adalah adanya peningkatan persentase kepuasan keluarga terhadap pelatihan komunikasi verbal yang diberikan 
oleh perawat. Pasien dan keluarga merasa puas dengan pelatihan komunikasi verbal. Selama latihan, beberapa alat bantu komunikasi non verbal digunakan untuk memfasilitasi pasien afasia, seperti foto, musik, gambar, buku komunikasi, papan alfabet dan alat tulis untuk mengurangi frustasi, depresi dan isolasi sosial.

Upaya melibatkan keluarga dalam rehabilitasi pasien stroke dengan gangguan komunikasi sangat diperlukan untuk meningkatkan efektifitas rehabilitasi. Pemulihan bahasa pasien sangat terbantu, jika keluarga memainkan perannya tersebut. Penelitian Sit, Wong, Clinton, Li \& Fong (2004) melaporkan bahwa family care giver pada pasien pasca stroke dapat meningkatkan kemampuan melakukan aktivitas hidup sehari-hari secara mandiri dan menjadi lebih baik dengan dukungan dan sosial support dari keluarga yang akan meningkatkan status kesehatan psiko-sosial pasien pasca stroke.

Hasil pengamatan, pasien mampu mengkomunikasikan kebutuhannya melalui pemberian buku komunikasi dan objek yang ada di sekitar ruangan dengan menunjukkan gambar, sehingga pasien dapat berinteraksi dengan keluarga dan petugas kesehatan. Pasien dibantu dengan menyediakan papan komunikasi. Papan komunikasi ini berisi gambar, kata-kata, huruf atau simbol aktivitas kegiatan harian pasien sesuai dengan kegiatan yang diminta atau diungkapkan. Pasien dianjurkan untuk mengungkapkan kebutuhan pribadi dan menggunakan papan tulis bila tidak mampu mengekspresikan kebutuhan.

Menurut hasil penelitian Finke, Light, dan Kitko (2008) bahwa komunikasi dengan alat bantu dapat membantu perawat berkomunikasi pada pasien yang mengalami keterbatasan komunikasi verbal. Penelitian ini diperkuat oleh Clarkson (2010) bahwa alat bantu komunikasi verbal dapat meningkatkan kemampuan komunikasi pasien, memperbaiki kehidupan seseorang dengan meningkatkan kemandirian dan perkembangan hubungan sosial, sehingga akan mempengaruhi kualitas hidup.

Secara keseluruhan pasien mampu menunjukkan gambar yang ada dibuku komunikasi dan benda-benda yang ada disekitar pasien untuk mengkomunikasikan kebutuhannya. Sebagian besar pasien mampu memberikan respon ya/tidak dan mengekspresikan kata-kata sederhana, seperti makan, minum, tidur tetapi mengalami kesulitan ketika berbicara dalam kalimat panjang, hanya kata-kata benda, makan, mandi. Aspek penilaian pemahaman, sebagian besar pasien mengalami kesulitan dalam memahami kalimat yang rumit. Pasien dapat merespon salam yang disampaikan melalui ekspresi wajah dan dapat berinteraksi dengan perawat.

Diharapkan dari mereka yang telah mengikuti sosialisasi dan pelatihan ini dapat menyebarluaskan kepada seluruh anggota keluargannya yang lain serta mampu melakukannya secara mandiri pada periode berikutnya. Hasil penelitian Amila (2013) merekomendasikan alat bantu komunikasi verbal menjadi salah satu alternatif intervensi untuk memfasilitasi komunikasi, sehingga dapat menurunkan depresi pasien stroke dengan afasia motorik (Amila, Sitorus, \& Herawati, 2015) 

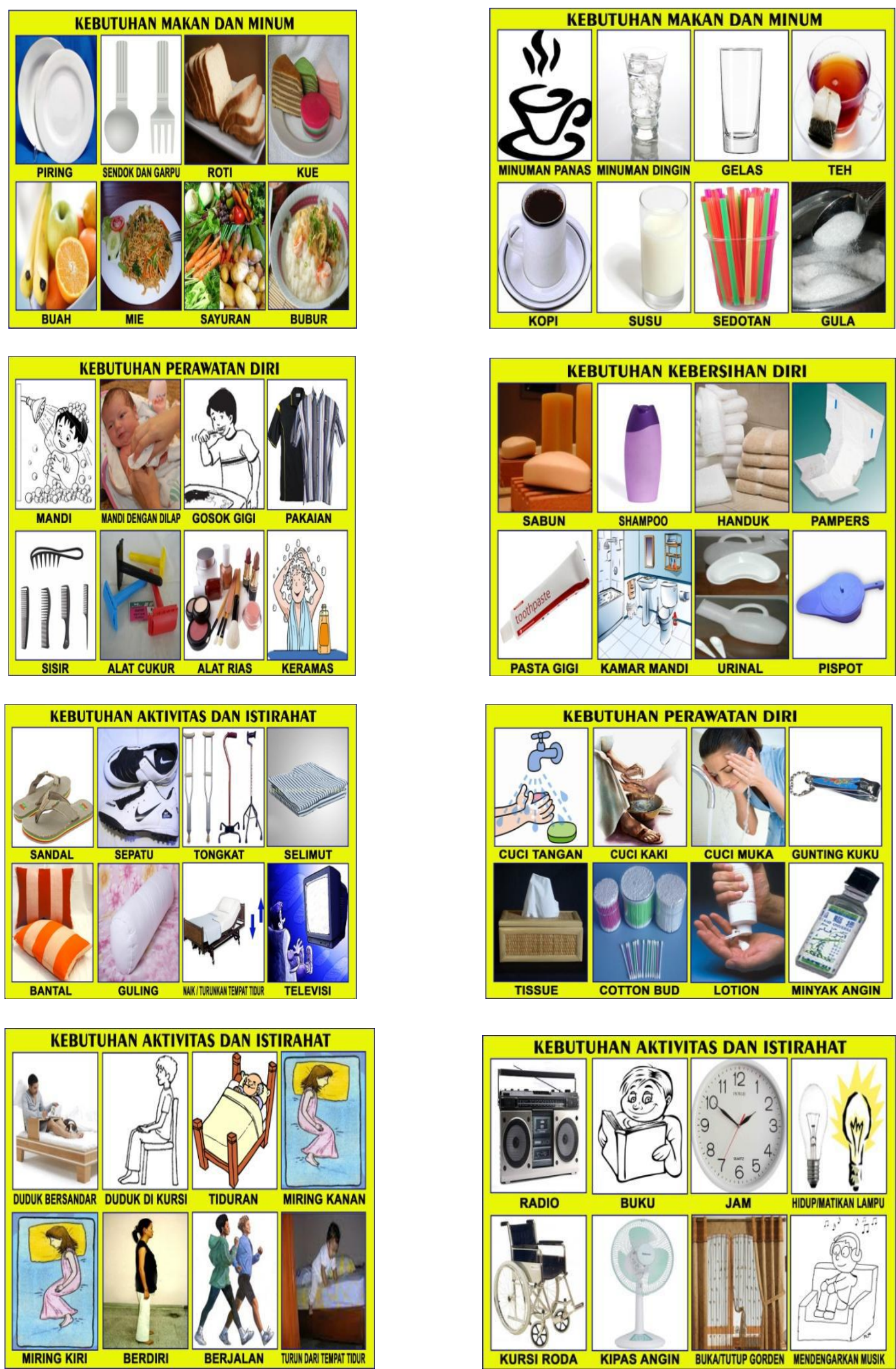

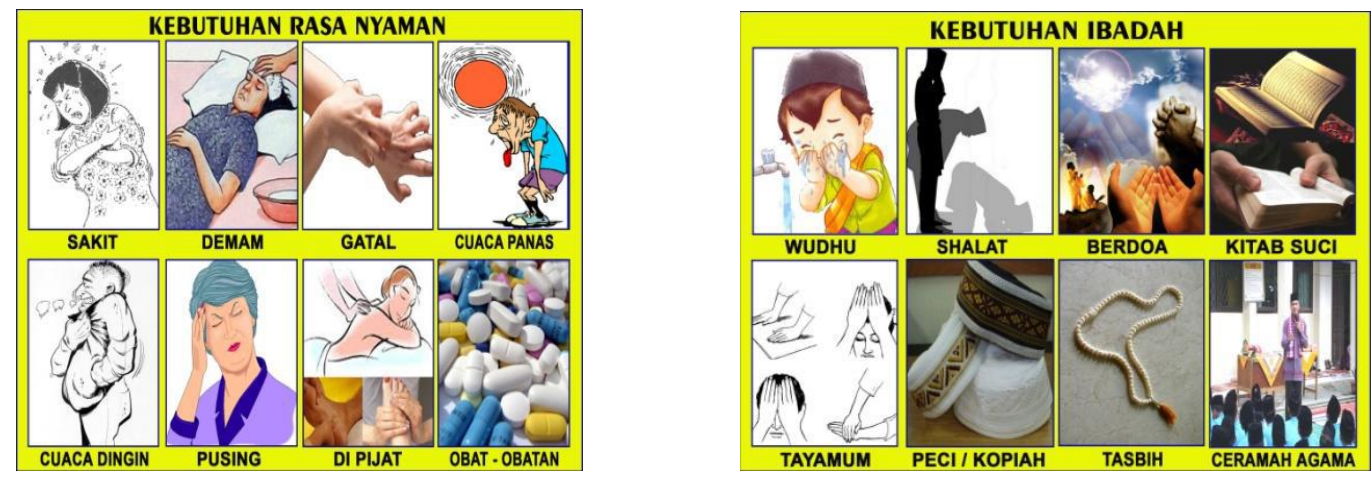

$\mathbf{S}$
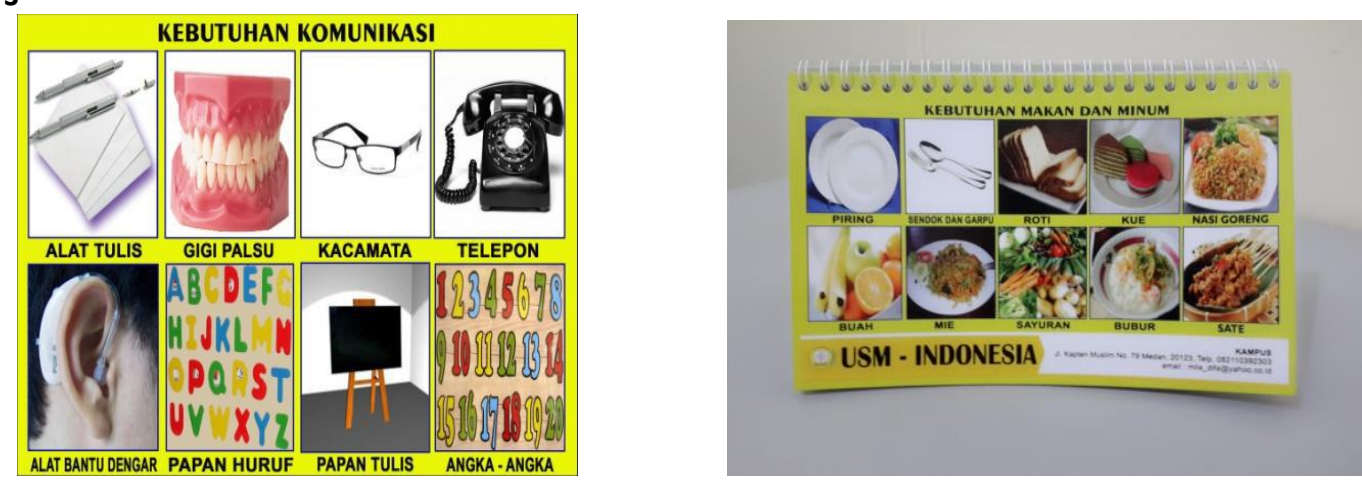

Gambar 2. Booklet Komunikasi Verbal

\section{Simpulan dan Rekomendasi}

Kegiatan Pengabdian kepada Masyarakat ini meningkatkan kepuasan pasien dan keluarga. Selama latihan, beberapa alat bantu komunikasi non verbal digunakan untuk memfasilitasi pasien afasia, seperti foto, musik, gambar, buku komunikasi, papan alfabet dan alat tulis untuk mengurangi frustasi, depresi dan isolasi sosial.

Disarankan untuk dikembangkan kemitraan yang luas, berupa pelatihan komunikasi verbal dan sosialisasi booklet komunikasi untuk meningkatkan interaksi sosial dan mengurangi depresi pasien dan keluarga.

\section{Acknowledgements}

Kegiatan Pengabdian kepada Masyarakat ini dibiayai oleh Direktur Pengabdian kepada Masyarakat dengan Nomor Kontrak .5.2.3.2.1/PPM/2018 Tanggal 16 April 2018 Program Multi Tahun, Tahun Anggaran 2019.

\section{Daftar Pustaka}

Amila, Sitorus, R., \& Herawati, T. (2015). Pengaruh Pemberian Augmentative and Alternative Communication ( AAC) Terhadap Kemampuan Funfsional. 18(2), 95-101.

Berman., Snyder., Kozier., \& Erb. (2008). Fundamentals of Nursing : Concepts, Process and Practice (8th ed.). New Jersey : Pearson International Edition.

Clarkson, K. (2010). Aphasia after stroke enabling communication through speech and language therapy. British Journal of Neuroscience Nursing, 6(5), 227-231. Jun - Jul 2010 
Finke, E.H., Light, J., \& Kitko, L. (2008). A systematic review of the effectiveness of nurse communication with patients with complex communication needs with a focus on the use of augmentative and alternative communication. Journal of Clinical Nursing. 2008 Aug; 17 (16) : 2102 - 2115.

Kusumoputro, S. (1992). Afasia : Gangguan berbahasa. Jakarta : Balai Penerbit FKUI.

Ministry of Health Indonesia. (2019). Profil Kesehatan Indonesia 2018 [Indonesia Health Profile 2018]. 207. Retrieved from http://www.depkes.go.id/resources/download/pusdatin/profil-kesehatanindonesia/Data-dan-Informasi_Profil-Kesehatan-Indonesia-2018.pdf

Nabyl, R.A. (2012). Deteksi Dini dan Gejala Pengobatan Stroke : Solusi Hidup Sehat Bebas Stroke. Edisi Cetakan 1. Yogyakarta : PT Aulia.

Salter, K., Jutai, J., Foley, N., Hellings, C., \& Teasell, R. (2006). Identification of aphasia poststroke : A review screening assesment tools. Brain injury, 20(6) : 559-568. June 2006.

Sit, J.W.,Wong, T.K.S., Clinton.,Li,L.S.W., \& Fong, Y.M. (2004). Stroke care in the home : The impact of social support on the general health of family caregivers. Journal of Clinical Nursing, 13: 816-824.

Thomas, S. A., \& Lincoln, N. B. (2008). Predictors of emotional distress after stroke. Stroke, 39(4), 1240-1245. https:/ / doi.org/10.1161/STROKEAHA.107.498279

Wikipedia. (2018).Augmentative and alternative communication therapy. http://en.wikipedia.org/wiki/Augmentative_and_alternative_communication. 